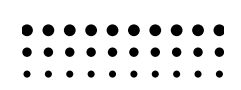

\title{
Jim Crow at the Ballot Box
}

7 here was a time when the United States believed that $\mathcal{L}$ only wealthy landowners should have a say in our democracy. Despite the assertion in the Declaration of Independence that all men were created equal, enslaved people were once considered only "property." But, over time, beginning with the 14th Amendment of the US Constitution, we saw an evolution that reflected the sentiment that our democracy should be more inclusive and live up to its founding ideals.

The implications of the Emancipation Proclamation, the Union victory over the secessionist Southern states, and the subsequent changes to the United States Constitution (the socalled Civil War amendments) were understandably a cultural shock to the slave owners and like-minded White Americans of the day. After all, slave owners believed with conviction that their slaves were inferior beings, undeserving 
of human dignity. And then they were suddenly being told that their slaves are people with rights; and the victors came into their states to enforce this new understanding. While this radical new view was still sinking in, these formerly enslaved people were already exercising their newfound rights by becoming active participants in the democratic process. They were voting and even getting elected to office. How alarming it must have been for the former slave owner to recognize the new state representative or senator as the son of the man he just recently whipped so brutally, or the son of the woman he once raped. As it's often said, "It ain't fun when the rabbit got the gun!"

In the minds of former slave owners, something had to be done, once their Southern states again had the power to act. In order to "right the wrongs" of the federal government's intrusion into the Southern social order, Jim Crow laws proliferated. The laws reestablished Black Americans as second-class citizens in Southern society, and through laws, violence, manipulation, and unfair implementation of various requirements, they also effectively eliminated Black enfranchisement.

But the cornerstone for the exceptional (and dubious) status of the United States as the only nation in the world where felons can be permanently stripped of their voting rights came from an unlikely source: the 14th Amendment of the United States Constitution itself, the very amendment that enfranchised former slaves. 
Section 2 of the 14th Amendment contains a key provision: its freedoms extended to all citizens "except for [those guilty of] participation in rebellion, or other crime." Here is the foundation for the implementation of felon disenfranchisement policies at the state level. Again, Florida's first constitution reads, "The General Assembly shall have the power to exclude from ... suffrage, all persons convicted of bribery, perjury, forgery, or other high crime, or misdemeanor." The 14th Amendment gave Florida's ruling elite all the justification they needed to continue this policy, even as Jim Crow made a farce of the equality the Amendment was meant to ensure. Even embedded in the bedrock of our freedom was a toehold for Jim Crow-it seemed inescapable, and eventually, inescapably partisan; whether it was the Dixiecrats or eventual Republicans, Jim Crow was a legal way to minimize potential negative electoral impact on one's political party.

In short, a century and a half later, when we at the Florida Rights Restoration Coalition began our campaign for change, we were facing a wall of history. The one exception was the Florida Correction Reform Act of 1974 which, for a flicker in time, had automatically restored civil rights, including voting rights, once an individual was released from prison or discharged from parole or probation. But the following year, the Florida Supreme Court had issued an advisory opinion that found the act to be unconstitutional because the state's constitution at the time gave the power of clemency exclusively 
to the governor and cabinet. Until 2018, and our attempt to remedy this antiquated law, there was only one way for disenfranchised people to get their voting rights back: they had to ask the state governor to restore those rights on a caseby-case basis through an opaque clemency process that took years and created tremendous hurdles. Even more important, the decision was arbitrary. When asked about what it takes to have voting rights restored, Florida governor Rick Scott replied: "There is no standard. We can do whatever we want." ${ }^{1}$ And that is exactly what he did. Governor Scott used the arbitrariness associated with his powers to shift what should have been the apolitical matter of granting clemency into a politicized one.

Governor Scott restored voting rights for fewer Black Floridians than any of the governors before him, Republican or Democrat, going back at least fifty years. To put this into perspective, in the four years of Governor Jeb Bush's administration, over 75,000 people were able to get their civil rights restored. In the four years of Governor Charlie Crist's administration, over 155,000 people were able to get their civil rights restored. But in the eight years of Governor Scott's administration, fewer than 5,000 of the 20,000 petitioners were successfully re-enfranchised. Scott also restored voting rights to a higher percentage of Republican voters and lower percentage of Democrats than any of his predecessors of either party since 1971. An analysis from the Palm Beach Post revealed that not only did Governor Scott's policy 
result in very few Floridians regaining voting rights, but the implementation of the policy favored White and Republican Floridians over Black and Brown voters. Although Blacks and Hispanics are incarcerated at much higher rates than Whites and comprise a much larger share of disenfranchised voters in the state, the Scott administration restored voting rights for twice as many Whites as Blacks during his years as governor.

I started to realize that even though the decision to restore civil rights should not have been a political one, it was left in the hands of politicians-people who needed to be voted into office. So, it was going to be difficult to get any governor, Republican or Democrat, to ignore the political ramifications of revising the clemency policy. In addition to the considerations of politicians, I also noticed the political consideration of voters. When faced with a purely political perspective on the restoration of voting rights, embedded in a conventional, biased assumption that it was mostly African Americans who were disenfranchised, the response was predictably grounded in a partisan calculus. Most Blacks vote Democratic. Therefore, when the question of re-enfranchisement came up, the Democrats were mainly for it, and the Republicans were mainly against it. I am not saying that this was true for everyone, but it was prevalent in the thousands of faceto-face discussions I've had throughout the state. Restoring voting rights to people with previous felony convictions was either a way to turn Florida "blue" (if you were talking to a 
Democrat) or a dastardly attempt by liberals to gain votes (if you were talking to a Republican).

Lost in those competing motivations was a greater consideration of simple fairness. Weed away the centuries of bias and the political realities associated with an evenly divided populace, and there were real people affected by the law. Real shame, embarrassment, and disaffection were living in the minds of American citizens who had repaid their debts to society, as well as in the minds of those who loved and supported them.

Disenfranchisement has a personal impact felt by real people, and it distorts what we want democracy to look like. Are we looking for a society in which the only outcome that matters is that our side wins? Or do we want a society that recognizes that democracy works better when we accept differing opinions, perspectives, and ideals, and affirm that everyone has the right to participate? I believe that a true champion of democracy should be motivated to protect and restore voting rights regardless of how the beneficiaries might vote. Advocacy for voting rights should be just as fervent for the people who don't agree with me as it is for those that do-and when I began a journey of hundreds of thousands of miles to talk to people all over Florida about returning citizens' need for a voice, that message resonated. It also led to the first successful constitutional challenge to that wall of historical injustice, creating the first cracks. 